\title{
Stable isotopic evidence of EI Niño-like atmospheric circulation in the Pliocene western United States
}

\author{
M. J. Winnick ${ }^{1}$, J. M. Welker ${ }^{2}$, and C. P. Chamberlain ${ }^{1}$ \\ ${ }^{1}$ Environmental Earth System Science, Stanford University, Stanford, CA 94305, USA \\ ${ }^{2}$ Environment and Natural Resources Institute and Department of Biological Sciences, University of Alaska Anchorage, \\ Anchorage, AK 99508, USA
}

Correspondence to: M. J. Winnick (mwinnick@stanford.edu)

Received: 1 September 2012 - Published in Clim. Past Discuss.: 16 October 2012

Revised: 12 March 2013 - Accepted: 14 March 2013 - Published: 8 April 2013

\begin{abstract}
Understanding how the hydrologic cycle has responded to warmer global temperatures in the past is especially important today as concentrations of $\mathrm{CO}_{2}$ in the atmosphere continue to increase due to human activities. The Pliocene offers an ideal window into a climate system that has equilibrated with current atmospheric $p \mathrm{CO}_{2}$. During the Pliocene the western United States was wetter than modern, an observation at odds with our current understanding of future warming scenarios, which involve the expansion and poleward migration of the subtropical dry zone. Here we compare Pliocene oxygen isotope profiles of pedogenic carbonates across the western US to modern isotopic anomalies in precipitation between phases of the El Niño-Southern Oscillation (ENSO). We find that when accounting for seasonality of carbonate formation, isotopic changes through the late Pliocene match modern precipitation isotopic anomalies in El Niño years. Furthermore, isotopic shifts through the late Pliocene mirror changes through the early Pleistocene, which likely represents the southward migration of the westerly storm track caused by growth of the Laurentide ice sheet. We propose that the westerly storm track migrated northward through the late Pliocene with the development of the modern cold tongue in the east equatorial Pacific, then returned southward with widespread glaciation in the Northern Hemisphere - a scenario supported by terrestrial climate proxies across the US. Together these data support the proposed existence of background El Niño-like conditions in western North America during the warm Pliocene. If the earth behaves similarly with future warming, this observation has important implications with regard to the amount and distribution of precipitation in western North America.
\end{abstract}

\section{Introduction}

As the earth's climate continues to respond to the anthropogenic input of greenhouse gasses to the atmosphere, understanding potential regional responses of the hydrologic cycle becomes vital for effective freshwater resource management and natural hazard mitigation policies. This problem is particularly relevant in water-vulnerable areas such as the Southwest United States where the amount of water used is similar to the amount of water available (Meehl et al., 2007). The current suite of Earth system models predicts an intensified hydrologic cycle with increasing global temperatures (Meehl et al., 2007). For many regions, this temperature increase is associated with increased precipitation. However, in the mid-latitudes where evaporation currently dominates precipitation such as in the Southwest US, a temperature increase results in decreasing precipitation due to the poleward expansion and enhanced aridification of the Hadley cell margin (Seager et al., 2007; O'Gorman and Schneider, 2009). This predicted regional response conflicts with reconstructed wetter-than-modern conditions in the Southwest during preQuaternary warm periods, particularly in the Pliocene epoch.

It is then of great importance to study the mechanisms behind increased precipitation during pre-Quaternary warm periods in regions that are projected to dry over the coming decades as a result of modern climate change. Herein, we examine terrestrial stable isotope records for the Pliocene of western North America in order to better understand the causes of these wetter-than-modern conditions despite higher global temperatures and a potentially strengthened hydrologic cycle. 
The Pliocene epoch (5.33-2.58 Ma), with similar-tomodern boundary conditions including atmospheric $p \mathrm{CO}_{2}$ of $\sim 400 \mathrm{ppm}$ (Pagani et al., 2010) and global geography (Zachos et al., 2001; Haug et al., 2001), affords us a unique view of a globally warmer equilibrium state of the Earth system (Jansen et al., 2007). During the Pliocene, global temperatures were $3-4{ }^{\circ} \mathrm{C}$ higher than today (Raymo et al., 1996; Haywood and Valdes, 2004), and major ice sheets were absent from the Northern Hemisphere (Zachos et al., 2001). In addition, much of the western and southern US were characterized by wetter-than-modern conditions, while a few areas in the Pacific Northwest were drier than modern (Fig. 1).

A number of studies have suggested that these anomalous wet conditions may have been the result of the temperature structure of the tropical Pacific. In the Pliocene, sea surface temperatures (SSTs) in the west equatorial Pacific were similar to modern, while SSTs in the east equatorial Pacific (EEP) were $3-5^{\circ} \mathrm{C}$ warmer with evidence of a much deeper thermocline (Wara et al., 2005; Dekens et al., 2007; Etourneau et al., 2010). In the modern climate, this temperature structure characterizes the El Niño phase of El Niño-Southern Oscillation (ENSO). This observation has led many studies to conclude that the Pliocene was characterized by a background El Niño-like state, though the nature of interannual variability is poorly constrained (Ravelo et al., 2004; Wara et al., 2005).

During modern El Niño years, North America is particularly affected by atmospheric teleconnections, as anomalous atmospheric conditions propagate poleward from the equatorial Pacific via planetary waves. Major changes in North American hydrology are primarily facilitated by a deeper Aleutian low, which forces the subtropical jet and westerly storm track equator-ward (Bjerknes, 1969; Trenberth et al., 1998). Qualitative spatial patterns of reconstructed Pliocene precipitation (wetter/drier) based on terrestrial proxy records match modern El Niño teleconnection patterns (Molnar and Cane, 2002) (Fig. 1), and GCM (general circulation model) experiments have shown that forced permanent El Niño-like SSTs result in a south-shifted subtropical jet and increased moisture convergence across the western and southern US (e.g., Barreiro et al., 2006; Shukla et al., 2009; Brierly and Federov, 2010; Vizcaíno et al., 2010; Goldner et al., 2011).

It has also been suggested that these wet conditions may have been the result of lower topography in the North American Cordillera (Bonham et al., 2009) based on PRISM 2 (Pliocene Research, Interpretation and Synoptic Mapping) boundary conditions. The assumption of lower topography, however, is not supported by paleoaltimetry studies of the US, which show that large-scale topography reached modern elevations by the early Miocene (e.g., Mulch et al., 2006; Mix et al., 2011; Chamberlain et al., 2012). More recently, Pliocene boundary conditions provided by PRISM 3 and used as part of the PlioMIP (Pliocene Model Intercomparison Project) have been amended to include near-modern topography across the western US (Sohl et al., 2009; Bragg et al., 2012). Results of PlioMIP ensembles using these

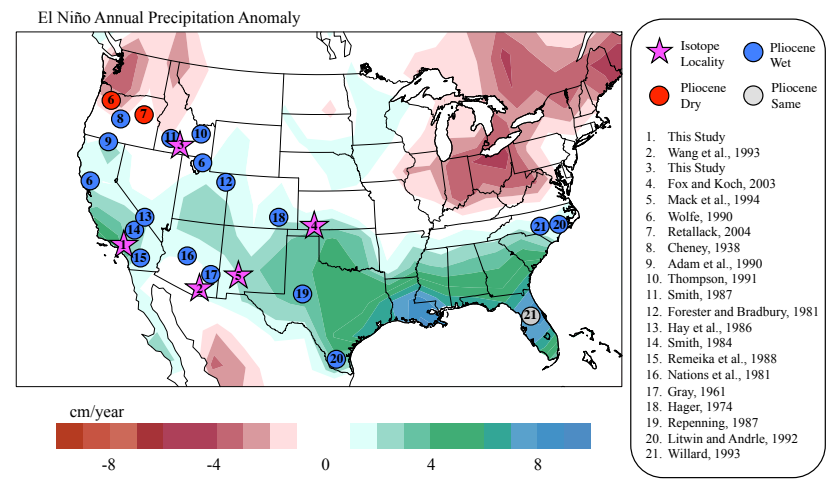

Fig. 1. Modern El Niño precipitation anomalies, isotope localities, and reconstructed Pliocene conditions. Anomalous annual El Niño precipitation calculated with CMAP precipitation data from 19792008; CMAP precipitation data provided by the NOAA/OAR/ESRL PSD, Boulder, CO, USA, from their Web site at http://www.esrl. noaa.gov/psd/. Purple stars show isotope record localities used in this study. Blue circles represent reconstructions of wetter-thanmodern Pliocene conditions, and red circles represent reconstructions of drier-than-modern Pliocene conditions.

updated boundary conditions indeed show enhanced precipitation rates over the western US likely resulting from the reduced zonal temperature gradient across the tropical Pacific, though there appear to be discrepancies with proxy-based reconstructions of precipitation across the southeastern US (Haywood et al., 2013).

In this study, we seek to test the hypothesis that wetterthan-modern Pliocene conditions in the western US were the product of a background El Niño-like state. To accomplish this, we compare two new and three previously published Plio-Pleistocene oxygen isotopic profiles across the western US measured in pedogenic carbonates with modern observations of isotopes in precipitation across two phases of ENSO (neutral and El Niño) at 77 stations across the country (Welker, 2012). Unlike flora-, fauna-, and sedimentbased reconstructions that record only local environmental conditions, isotopes in precipitation recorded in authigenic minerals are controlled by a combination of local conditions and upstream processes such as rainout and moisture transport (e.g., Pausata et al., 2011; Poulsen et al., 2010). While separating local signals from upstream signals is often challenging, oxygen isotopes therefore have the potential to offer unique insights into synoptic-scale atmospheric circulation.

\section{Methods}

\subsection{Pedogenic carbonates}

We sampled two well-dated sections composed of Pliocene paleosols and fluvial deposits that contain abundant pedogenic carbonate: (1) the San Timoteo Badlands of southern California (CA) (Albright, 1999) on the windward corner of 
the intersection of the Transverse and Peninsular ranges, and (2) the sections located at Hagerman, Idaho (ID), from the Glenns Ferry, Tuana Gravels, and Bruneau formations (Hart et al., 1999; Sadler and Link, 1996; Amini et al., 1984). We collected calcareous sand- and mudstones showing no physical signs of re-precipitation of carbonate such as weathered surfaces or calcite veins. Milled carbonate samples were reacted with phosphoric acid through a Kiel III carbonate device. Carbon and oxygen isotope ratios were then measured on a Thermo Finnigan DELTAplus. Precision of carbonate $\delta^{18} \mathrm{O}$ values is $\sim 0.06 \%$ based on repeated analyses of NBS19 and M-2 carbonate standards. These isotope values are given in Table S1 in the Supplement.

In addition to these new isotope records, we compiled three previously published isotopic profiles of pedogenic carbonates that are found in Plio-Pleistocene sections in the western US. These profiles were collected from Camp Rice, New Mexico (NM) (Mack et al., 1994), Meade, Kansas (KS) (Fox and Koch, 2003), and St David, Arizona (AZ) (Wang et al., 1993) (Fig. 1). Taken together, these locations allow us to compare isotopic signals across a broad spatial range of the western US, which has not previously been attempted.

These sites represent a range of seasonal climates as shown in Fig. 2. In San Timoteo, CA, the majority of precipitation occurs during the winter months via the westerly storm track with very little precipitation during the summer months. The sites in St David, AZ, and Camp Rice, NM, receive the majority of their precipitation from the North American monsoon during the summer months. They also receive moisture from the westerly storm track during the winter months, with spring being the driest time of the year. Hagerman, ID, experiences relatively dry conditions throughout the year with reduced seasonality and the majority of precipitation coming from the Pacific. Finally, precipitation in Meade, KS, occurs primarily in the spring and early summer months with moisture delivered from the Gulf of Mexico via the Great Plains low-level jet.

Measured isotope values are left as $\delta^{18} \mathrm{O}_{\text {carbonate }}$ for analysis rather than converting to $\delta^{18} \mathrm{O}_{\text {precip }}$, as regional temperature evolution over this time period is poorly constrained. As a result, our comparisons between paleo- and modern data are limited to relative changes rather than absolute values. We correct for changing $\delta^{18} \mathrm{O}$ of seawater due to the initiation of terrestrial Northern Hemisphere glaciation. This correction involves a linear increase in $\delta^{18} \mathrm{O}_{\text {sea }}$ of $0.39 \%$ o between 3.6 and 2.4 Ma based on mean ocean records (Mudelsee and Raymo, 2005).

\subsection{Modern isotopes in precipitation}

Weekly precipitation samples collected as part of the National Atmospheric Deposition Network were analyzed for $\delta^{18} \mathrm{O}$ and $\delta \mathrm{D}$ values as part of the United States Network for Isotopes in Precipitation (USNIP) (Welker, 2012, 2000). We use this dataset in our analysis as it represents over

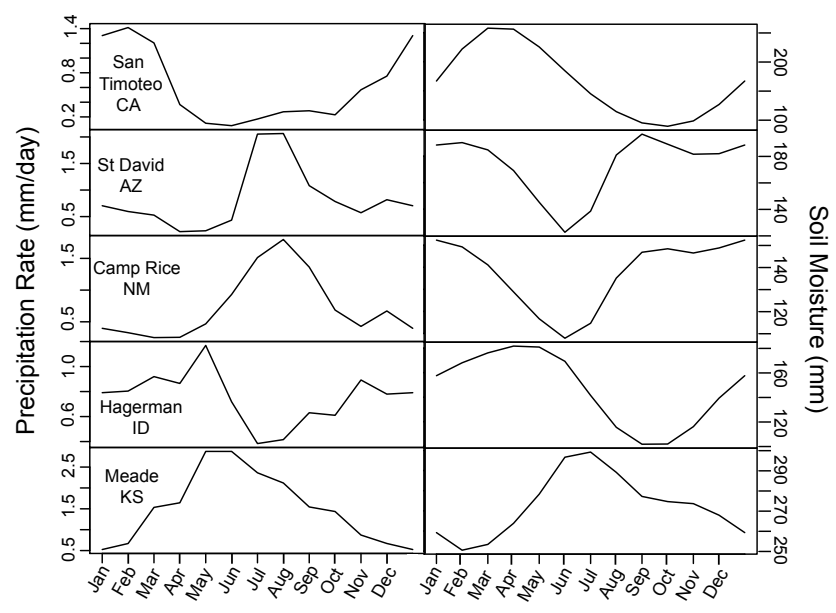

Fig. 2. Average monthly precipitation rates (right) and soil moisture (left) at each site. Precipitation data calculated from CMAP 19792000 (ref. in Fig. 1) and soil moisture calculated from from NOAA Climate Prediction Center 1971-2000 (van den Dool et al., 2003) at each of the isotope localities.

10000 samples of weekly precipitation collected from 77 sites across the US between 1989 and 1995 (Welker, 2012). We binned these samples into El Niño and neutral phases based the Southern Oscillation Index. We then subdivided these phases into JFM (winter), AMJ (spring), JAS (summer), and OND (autumn) seasons. Seasonal average $\delta^{18} \mathrm{O}$ was calculated for each site using precipitation amountweighted averages of raw weekly isotopic values. The El Niño isotopic anomalies given in this paper are the difference between El Niño and neutral seasonal averages at each site $\left(\Delta \delta^{18} \mathrm{O}\right)$. Finally, we used a 12-point spherical kriging interpolation in ArcGIS to generate seasonal maps of precipitation $\delta^{18} \mathrm{O}$ anomalies.

\section{Results}

\subsection{Pedogenic carbonates}

Oxygen isotopic records are presented in Fig. 3a-e. These records show two contrasting trends that are dependent upon geographic location. First, in the Southwest US we observe a decrease in $\delta^{18} \mathrm{O}$ of carbonate through the late Pliocene followed by an increase through the early Pleistocene. For example, in the section located at St David, AZ, $\delta^{18} \mathrm{O}$ decreases by $3 \%$ through the late Pliocene, then increases by $2 \%$ through the early Pleistocene. Similarly, $\delta^{18} \mathrm{O}$ decreases by $4 \%$ through the late Pliocene in sections at San Timoteo, $\mathrm{CA}$, and increases by $3 \%$ o through the early Pleistocene in Camp Rice, NM.

In contrast, $\delta^{18} \mathrm{O}$ values in the Great Plains and Northwest interior increase through the late Pliocene and decrease through the early Pliocene. The $\delta^{18} \mathrm{O}$ values of pedogenic carbonates from Meade, KS, increase by $2 \%$ through the 


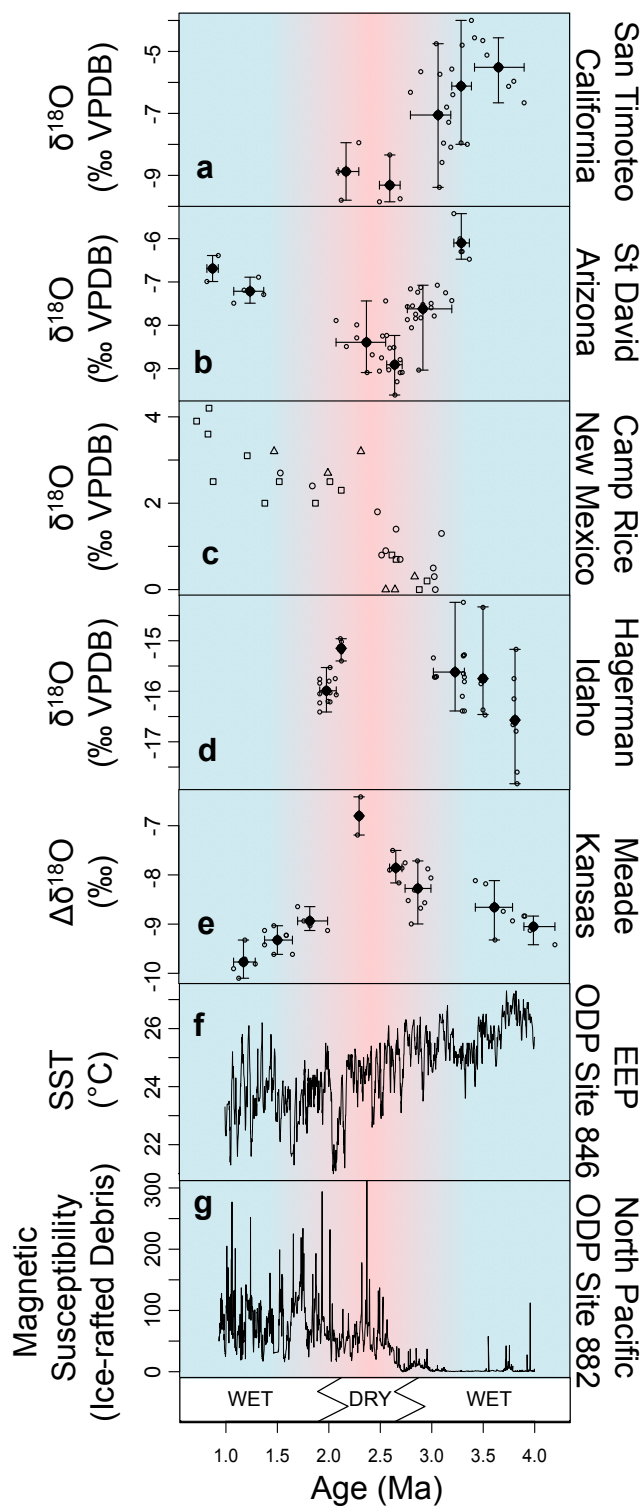

Fig. 3. Isotope stratigraphies from (a) San Timoteo, CA, (b) St David, AZ (Wang et al., 1993), (c) Camp Rice, NM (Mack et al., 1994), (d) Hagerman, ID, and (e) Meade, KS (Fox and Koch, 2003). Open circles in (a-d) represent individual samples, filled circles binned averages, and error bars bin ranges. Camp Rice, NM, values normalized to sub-locality minimum values, and circles, triangles, squares represent sub-localities Hatch Siphon, Rincon Arroyo, Lucero Arroyo, respectively. (f) Reconstructed SSTs in the east equatorial Pacific ODP Site 846 show development of the modern cold tongue (Lawrence et al., 2006). (g) Magnetic susceptibility at ODP Site 882 in the North Pacific shows ice-rafted debris and expansion of $\mathrm{NH}$ glaciation through the Pleistocene (Maslin et al., 1995). Climatic conditions (wet/dry) in the western US are shown at the bottom and in blue and red background based on compilation of proxy-based reconstructions (Thompson, 1991). late Pliocene, then decrease by $2 \%$ through the early Pleistocene. Three $\delta^{18} \mathrm{O}$ values of carbonate from this section are excluded at $\sim 2.4 \mathrm{Ma}$, as these values are anomalously high (by 6-9\%o) and clearly represent extensive evaporative enrichment that masks changes in precipitation (Fox and Koch, 2003). Finally, though temporal coverage is relatively poor, $\delta^{18} \mathrm{O}$ values in Hagerman, ID, increase by as much as $4 \%$ o across the late Pliocene and decrease by $\sim 1 \%$ across the early Pleistocene.

One feature that is consistent between all of the locations that span both the late Pliocene and early Pleistocene is a characteristic "V" shape with a local min/max within estimated dating errors of the Pliocene-Pleistocene boundary. Consequently, carbonate $\delta^{18} \mathrm{O}$ values in the mid-Pleistocene (ca. $1 \mathrm{Ma}$ ) approach mid-Pliocene (ca. 4.0 Ma) values in these sections regardless of the direction of change. Isotopic trends in the San Timoteo, CA, and Camp Rice, NM, sections also reverse initially around the Plio-Pleistocene boundary.

The structure of the isotope records and the fact that the direction of changes is regionally dependent strongly suggest that oxygen isotope signals are primarily affected by atmospheric circulation changes rather than changes in temperature or local rainfall amount. Regional temperature evolution through this time period is not well constrained, though global reconstructions show temperature decreased across the late Pliocene on the order of $1.1-1.6^{\circ} \mathrm{C}$ (see Pagani et al., 2010). The temperature effects on $\delta^{18} \mathrm{O}_{\text {calcite }}$ values are approximately $0.35 \% 0^{\circ} \mathrm{C}^{-1}$, based on the combined relationships between temperature of precipitation and its oxygen isotope composition (Rozanski et al., 1993) and the equilibrium isotopic fractionation between carbonate and water (Kim and O'Neil, 1997). Assuming a liberal $2^{\circ} \mathrm{C}$ of cooling across the late Pliocene, this should translate into a decrease in $\delta^{18} \mathrm{O}$ values of $\sim 0.7 \%$ at all sites, which, if present, is masked under the larger observed signals.

Additionally, terrestrial proxy-based climatic reconstructions show similar decreases/increases in rainfall amount at or in the vicinity of all isotope localities through the Pliocene/Pleistocene (Fig. 1; Thompson, 1991). While there is likely spatial heterogeneity in the magnitude of these changes, we would expect to observe increasing/decreasing $\delta^{18} \mathrm{O}$ through the Pliocene/Pleistocene at all locations based on the local "amount effect". As we do not observe this, we eliminate local rainfall amount as a dominant driver of isotopic change across this time interval. In addition, we do not believe these records are responding to changes in orography (see Supplement).

\subsection{Modern isotopes in precipitation}

Modern seasonal precipitation $\delta^{18} \mathrm{O}$ anomalies during El Niño years as compared to neutral years from 1989-1995 are shown in Fig. 4 (Welker, 2012). During the fall months (OND), negative $\delta^{18} \mathrm{O}$ anomalies occur primarily in the Southwest and Great Plains, and are on the order of $-4 \%$ o 

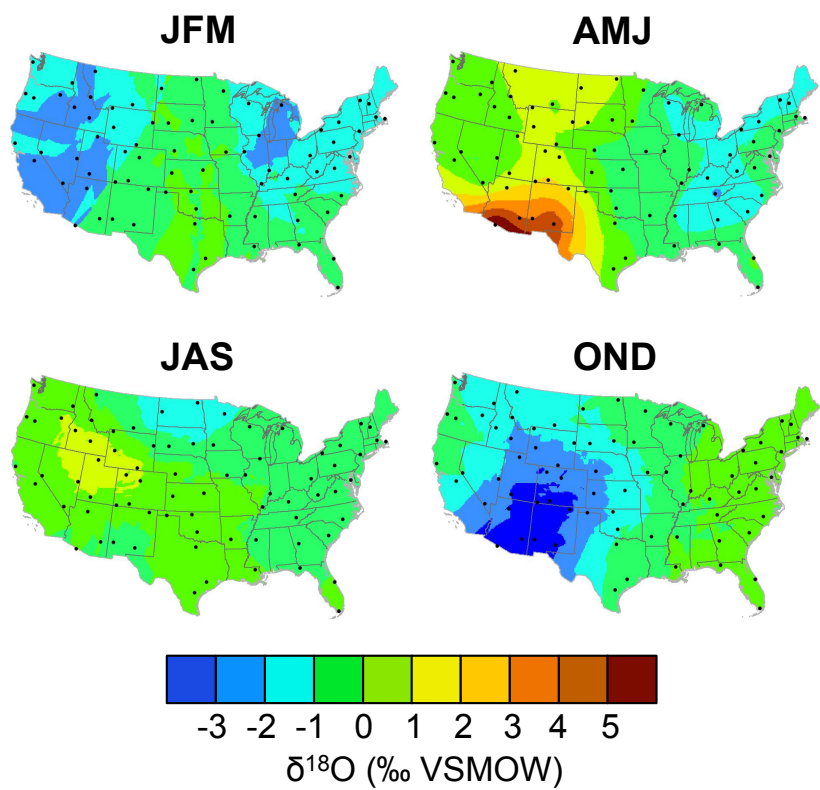

Fig. 4. Modern seasonal El Niño isotope anomalies. Black circles represent USNIP station sites. Figure modified from Welker (2012).

to $-3 \%$. During El Niño winters (JFM), negative anomalies on the order of $-3 \%$ to $-2 \%$ occur over the west coast and around the Great Lakes. Large positive anomalies on the order of 3-6\%o characterize the Southwest, while small negative anomalies occur over the eastern US in the spring (AMJ). Anomalies are minimal during the summer (JAS) with small positive anomalies over southern Idaho/northern Utah and small negative anomalies over North Dakota. It is important to note that, for specific regions, isotopic anomalies are seasonally distinct. For example, the Southwest experiences large negative anomalies in the fall and large positive anomalies in the spring.

The fact that the largest anomalies are located in the Southwest is consistent with the region's sensitivity to changes in the position of the Pacific jet as shown in the modern climate (Ropelewski and Halpert, 1986) and in the past via forcing from the North Atlantic (Wagner et al., 2010; Asmerom et al., 2010). There are small correlations between site elevation and $\delta^{18} \mathrm{O}$ anomalies in the spring and fall $\left(r^{2}=0.16\right.$ and 0.24 , respectively), as the largest anomalies occur in the high-elevation Southwest. However, we believe this is due to the region's sensitivity to ENSO rather than elevation itself.

While we incorporate over 10000 separate weekly measurements of isotopes in precipitation in our analysis of modern ENSO signals, the time interval of observations is only $6 \mathrm{yr}$ and does not include large El Niño events such as those that took place in 1997-1998. In order to validate these observed signals as robust features of ENSO teleconnections, we compared observations to reanalysis-driven isotope-tracking model data from 1950-2003 and found modeled ENSO signals over the past half-century largely match those observed from 1989-1995 (see Supplement).

\section{Discussion}

\subsection{Seasonality of carbonate formation}

In order to compare modern observations of isotopes in precipitation with isotopes of pedogenic carbonates, we must consider seasonal biases of pedogenic carbonates at each locality, as modern soil carbonates have been shown to form during discreet seasonal intervals that are regionally distinct (Breecker et al., 2009; Stevenson et al., 2010; Peters et al., 2013). Accounting for the seasonal bias in the soil carbonate records presented is of particular importance considering regional $\delta^{18} \mathrm{O}$ anomalies in $\mathrm{El}$ Niño precipitation are seasonally dependent.

Pedogenic carbonate formation occurs as soils dry, both through the associated decrease in soil $p \mathrm{CO}_{2}$ as microbial respiration rates slow and as carbonate becomes increasingly saturated in soil water through evapotranspiration, following the wet season and peak primary productivity (Breecker et al., 2009; Peters et al., 2013; McFadden and Tinsley, 1985; McFadden et al., 1991; Retallack, 2005). Evidence for carbonate formation during times of drying of soils is supported by depth profiles of oxygen isotopes in soils. Typical soil profiles show increasing $\delta^{18} \mathrm{O}_{\text {carbonate }}$ values near the soil surface (Quade et al., 1989; Liu et al., 1996), an effect caused by the upward wicking of soil water and downward diffusion of the isotopically heavier water as a soil dries (Barnes and Allison, 1983). We therefore assign carbonate growth to occur as average monthly precipitation reaches a minimum and soil moisture decreases.

In the Southwest region including the San Timoteo, CA, St David, AZ, and Camp Rice, NM, localities, monthly precipitation reaches a minimum and soil moisture decreases dramatically in the spring (AMJ) following the winter westerly storms (Fig. 2). This observation is consistent with the empirical finding of Breecker et al. (2009) that carbonate formation in the Southwest occurs primarily in the spring. In the Great Plains including the Meade, KS, locality, minimum monthly precipitation and decreasing soil moisture occurs primarily in the fall (OND) following the wet summer growth season (Fig. 2). Finally in the Northwest interior including the Hagerman, ID, locality, soil moisture decreases as monthly precipitation reaches a minimum in the summer (JAS) (Fig. 2). However, an empirical study of this region found that dry areas (MAP $<400 \mathrm{~mm}$ ) with weak seasonality of rainfall form carbonates in the winter as well (Stevenson et al., 2010). We then model the season of carbonate formation at Hagerman, ID, with both summer and winter as two possible end-member scenarios.

In this analysis, we make the assumption that Pliocene seasonality was not significantly different from the modern. While there were undoubtedly changes in precipitation in the western US during the Pliocene, a survey of Pliocene GCM studies suggests that the overall patterns of precipitation seasonality were similar to today in the regions relevant 
to our study. In the Southwest, models predict wetter winter conditions, while spring-summer conditions were similar to or drier than modern (Barreiro et al., 2006; Vizcaino et al., 2010; Goldner et al., 2011), resulting in a strengthened version of the modern seasonality pattern (Fig. 2). In the Great Plains region, models predict increases in summer precipitation with little to no change in fall-winter precipitation (Barreiro et al., 2006; Haywood et al., 2007; Shukla et al., 2009; Vizcaino et al., 2010; Goldner et al., 2011), again strengthening the modern pattern of seasonality (Fig. 2). In all cases, these changes may have acted to shift carbonate formation to later in the season, though the quantification of this shift is not possible.

\subsection{Comparison of Pliocene and modern isotope signals}

A comparison of the observed Plio-Pleistocene changes in carbonate $\delta^{18} \mathrm{O}$ with calculated changes in $\delta^{18} \mathrm{O}$ between $\mathrm{El}$ Niño and neutral years $\left(\Delta \delta^{18} \mathrm{O}\right)$ at each locality based on observed seasonal El Niño anomalies and the estimated season of soil carbonate formation is shown in Fig. 5. Observed $\Delta \delta^{18} \mathrm{O}$ of pedogenic carbonates across the late Pliocene matches calculated changes associated with a shift from El Niño to neutral circulation in the modern climate at three of the four analyzed localities - Meade, KS, St David, CA, and San Timoteo, CA. The Hagerman, ID, site presents a more complicated scenario, however. If carbonate $\delta^{18} \mathrm{O}$ is representative of winter precipitation, as it most likely is in the modern climate based on regional empirical analyses of carbonate formation in this region (Stevenson et al., 2010), then the change in $\delta^{18} \mathrm{O}$ at the Hagerman, ID, site is consistent with the observed change from El Niño to neutral background circulation across the late Pliocene. If carbonate $\delta^{18} \mathrm{O}$ is representative of summer precipitation, potentially due to higher Pliocene mean annual precipitation, however, the observed shift does not support the transition from El Niño to neutral circulation at the Hagerman site.

These results suggest that the evolution of atmospheric circulation through the Pliocene resembled the modern transition from El Niño to neutral phases of ENSO. This is consistent with both modeling studies that show El Niño-like conditions across the US forced with reconstructed tropical Pacific SSTs and with the reconstructed development of the modern EEP cold tongue through the late Pliocene (Fig. 3f).

Local environmental signals may have interacted with those of changing atmospheric circulation as well. Specifically, increases in local soil evaporation with regional aridification may have led to increasing $\delta^{18} \mathrm{O}$ values through the Pliocene. This signal would act to amplify the El Niño signals at the KS locality and dampen the El Niño signals at the $\mathrm{AZ}$ and CA localities. In addition, a potential shift of carbonate formation to earlier in the season through the Pliocene as mentioned above may have amplified El Niño signals at the CA, AZ, and KS sites: in CA and AZ with a shift towards the incorporation of isotopically lighter winter precipitation,

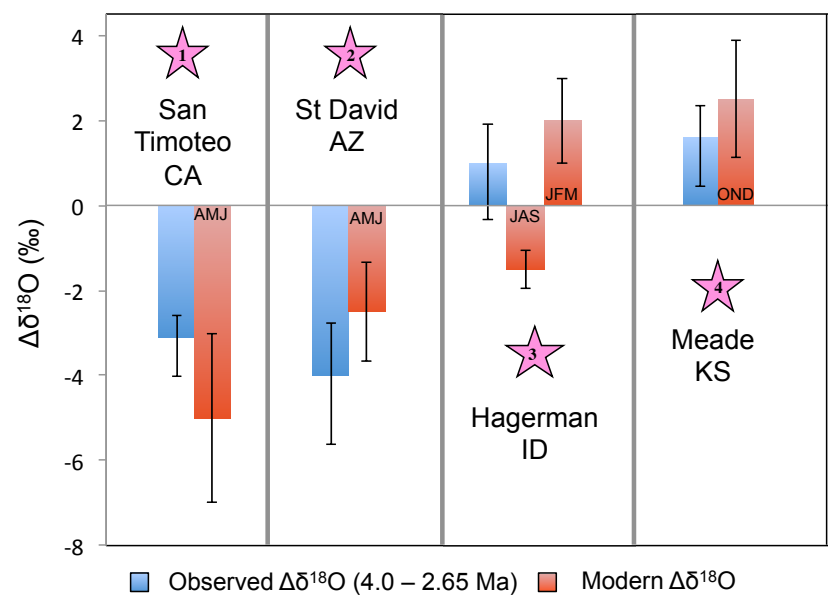

Fig. 5. Comparison of observed Pliocene $\Delta \delta^{18} \mathrm{O}$ with modern $\mathrm{El}$ Niño $\delta^{18} \mathrm{O}$ anomalies. Error bars in observed $\Delta \delta^{18} \mathrm{O}$ values show $95 \%$ confidence intervals in differences between relevant sample bins. Error bars in modern El Niño anomalies show $95 \%$ confidence intervals from calculated kriging prediction errors. Numbered stars correspond to labeling in Fig. 1.

and in Kansas through a shift towards the incorporation of isotopically heavy summer precipitation. The potential contributions of these local conditions to observed signals are speculative and cannot be quantified.

\subsection{Comparison of Pliocene and Pleistocene isotope signals}

In addition to this line of evidence, comparisons between carbonate $\delta^{18} \mathrm{O}$ values from mid-Pliocene and mid-Pleistocene paleosols also support the idea that wetter-than-modern Pliocene conditions in the western US were a product of $\mathrm{El}$ Niño-like circulation. The Plio-Pleistocene boundary is characterized by the initiation and rapid expansion of glaciation in the Northern Hemisphere (Zachos et al., 2001). Northern Hemisphere glaciation, independent of the longitudinal location of ice sheet growth, causes a series of atmosphereocean teleconnections that propagate to the tropics resulting in a south-shifted ITCZ (Intertropical Convergence Zone) in all three major ocean basins (Chiang and Bitz, 2005). A south-shifted ITCZ in turn creates a deeper Aleutian low and shifts the Pacific jet southwards across the western US (Trenberth et al., 1998; Chiang and Bitz, 2005), similar to El Niño circulation. Studies that reconstruct climate during periods of Northern Hemisphere glaciation caused by orbital and North Atlantic freshwater forcing in the Quaternary with both proxy data and models observe a deeper Aleutian low and subsequent southward-shifted Pacific jet, which enhances moisture delivery to the Southwest (e.g., Clark et al., 1999; Wagner et al., 2010; Asmerom et al., 2010).

The fact that mid-Pliocene $\delta^{18} \mathrm{O}$ values are similar to midPleistocene values at all sites that span this time interval 
suggests that atmospheric circulation in the mid-Pliocene resembled that of the mid-Pleistocene. Specifically, the Pacific subtropical jet was displaced farther south allowing the enhanced delivery of moisture to the Southwest. In the absence of large-scale glaciation during the mid-Pliocene, the observed El Niño-like SST structure of the equatorial Pacific provides a well-understood mechanism that causes this circulation regime over the western US.

In our proposed scenario, the "V" pattern of $\delta^{18} \mathrm{O}$ observed in Plio-Pleistocene pedogenic carbonates represents the poleward migration of the subtropical jet with the decay of El Niño-like SSTs and development of the EEP cold tongue through the late Pliocene, followed by a southward redirection of the subtropical jet beginning at the Plio-Pleistocene boundary by the large-scale expansion of glaciation in the Northern Hemisphere. This scenario is consistent with the timing of previous reconstructions of the EEP cold tongue (Lawrence et al., 2006; Fig. 3f) and Northern Hemisphere glaciation (Maslin et al., 1995; Fig. 3g). This scenario is also consistent with compilations of fauna-, flora-, pollen-, and sediment-based reconstructions of climate evolution, as well. Across the western US, there is a general pattern of wetterthan-modern conditions through the Pliocene, followed by a period of increased aridity around the Pliocene-Pleistocene boundary, and finally a return to wetter-than-modern conditions by the mid-Pleistocene (Thompson, 1991; Fig. 3).

\section{Conclusions}

In summary, we have compared $\delta^{18} \mathrm{O}$ values from pedogenic carbonates at multiple sites across the western US through the Plio-Pleistocene with modern $\delta^{18} \mathrm{O}$ changes in precipitation between phases of the El Niño-Southern Oscillation to test the hypothesis that reduced zonal SST gradients in the tropical Pacific resulted in El Niño-like circulation - specifically in a south-shifted Pacific jet. The isotopic signals we observe match modern differences between El Niño and neutral phases of ENSO and are consistent with the predicted response of the Pacific jet to the development of modern zonal SST gradients through the late Pliocene in terms of direction, magnitude, and timing. In addition, convergence on mid-Pliocene $\delta^{18} \mathrm{O}$ values during the mid-Pleistocene in pedogenic carbonates at localities that cover the interval suggests similar circulation conditions during these two time intervals. Circulation during the mid-Pleistocene is currently better constrained and was characterized by a deep Aleutian low and south-shifted Pacific jet, similar to El Niño circulation. Together, we see these as strong evidence that reconstructed wetter-than-modern conditions in the Pliocene western US, despite warmer global temperatures, were in fact a product of the background El Niño-like temperature structure of the tropical Pacific.

This finding is also broadly consistent with the initial results of PlioMIP ensemble data run with PRISM 3 boundary conditions, which show increased precipitation over the western US as a result of the reduced zonal temperature gradient across the tropical Pacific (Haywood et al., 2013). Future work addressing the nature of tropical Pacific teleconnections encapsulated in these ensemble data along with the use of isotope-enabled GCMs run with PlioMIP boundary conditions will allow for an unprecedented level of datamodel comparison.

Finally, while idealized GCM experiments have demonstrated the dynamical effects of a background El Niñolike tropical Pacific on Pliocene climate (e.g., Barreiro et al., 2006; Shukla et al., 2009; Brierly and Federov, 2010; Vizcaíno et al., 2010; Goldner et al., 2011), the mechanisms leading to this state are still debated (e.g., Federov et al., 2006, 2010). The identification of these mechanisms and their relevance to modern climate change is of the utmost importance to freshwater resource management in the western US as well as other regions affected by atmospheric teleconnections from the tropical Pacific.

\section{Supplementary material related to this article is available online at: http://www.clim-past.net/9/903/2013/ cp-9-903-2013-supplement.zip.}

Acknowledgements. We would like to acknowledge Peter Blisniuk, Rob Dunbar, and David Mucciarone for laboratory assistance and space as well as Rob Dunbar, Kate Maher, and Noah Diffenbaugh for useful comments and suggestions on this project. We would like to thank Walter Torres, Jeremy Caves, and Hari Mix for fieldwork and laboratory assistance. We also thank two anonymous reviewers for suggestions and edits that improved an earlier version of this paper. This research has been supported in part by NSF grants DBI 0923517 and AGS 0080952 awarded to J.M.W. and EAR 1019648 awarded to C.P.C.

Edited by: A. Haywood

\section{References}

Adam, D. P., Bradbury, J. P., Rieck, H. J., and Sarna-Wojcicki, A. M.: Environmental changes in the Tule Lake Basin, Siskiyou and Modoc Counties, California, from 3 to 2 million years before present, Geol. Soc. Am. Bull., 13 pp., 1990.

Albright, L. B.: Magnetostratigraphy and biochronology of the San Timoteo Badlands, southern California, with implications for local Pliocene-Pleistocene tectonic and depositional patterns, Geol. Soc. Am. Bull., 111, 1265-1293, 1999.

Amini, H., Mehnert, H. H., and Obradovich, J. D.: K-Ar ages of late Cenozoic basalts from the western Snake River Plain, Idaho, Isochron/West, 41, 7-11, 1984.

Asmerom, Y., Polyak, V. J., and Burns, S. J.: Variable winter moisture in the southwestern United States linked to rapid glacial climate shifts, Nat. Geosci., 3, 114-117, 2010. 
Barnes, C. J. and Allison, G. B.: The distribution of deuterium and ${ }^{18} \mathrm{O}$ in dry soils: 1. Theory, J. Hydrol., 60, 141-156, 1983.

Barreiro, M., Philander, G., Pacanowski, R., and Federov, A.: Simulations of warm tropical conditions with application to middle Pliocene atmospheres, Clim. Dynam., 26, 349-365, 2006.

Bjerknes, J.: Atmospheric teleconnections from the equatorial Pacific, Mon. Weather Rev., 97, 163-172, 1969.

Bonham, S., Haywood, A., Lunt, D., Collins, M., and Salzmann, U.: El Niño-Southern Oscillation, Pliocene climate and equifinality, Philos. T. R. Soc. A., 367, 127-156, 2009.

Bragg, F. J., Lunt, D. J., and Haywood, A. M.: Mid-Pliocene climate modelled using the UK Hadley Centre Model: PlioMIP Experiments 1 and 2, Geosci. Model Dev., 5, 1109-1125, doi:10.5194/gmd-5-1109-2012, 2012.

Breecker, D. O., Sharp, Z. D., and McFadden, L. D.: Seasonal bias in the formation and stable isotopic composition of carbonate in modern soils from central New Mexico, USA, Geol. Soc. Am. Bull., 121, 630-640, 2009.

Brierly, C. M. and Federov, A. V.: Relative importance of meridional and zonal sea surface temperature gradients for the onset of the ice ages and Pliocene-Pleistocene climate evolution, Paleoceanography, 25, PA2214, doi:10.1029/2009PA001809, 2010.

Chamberlain, C. P., Mix, H. T., Mulch, A., Hren, M. T., KentCorson, M. L., Davis, S. J., Horton, T. W., and Graham, S. A.: The Cenozoic climatic and topographic evolution of the western North American Cordillera, Am. J. Sci., 312, 213-262, 2012.

Cheney, R. W.: The Deschutes flora of eastern Oregon, Publications of the Carnegie Institution of Washington, 476, 187-216, 1938.

Chiang, J. C. H. and Bitz, C. M.: Influence of high latitude ice cover on the marine Intertropical Convergence Zone, Clim. Dynam., 25, 477-496, 2005.

Clark, P. U., Alley, R. B., and Pollard, D.: Northern Hemisphere icesheet influences on global climate change, Science, 286, 11041111, 1999.

Dekens, P. S., Ravelo, A. C., and McCarthy, M. D.: Warm upwelling regions in the Pliocene warm period, Paleoceanography, 22, PA3211, doi:10.1029/2006PA001394, 2007.

Etourneau, J., Schneider, R., Blanz, T., and Martinez, P.: Intensification of the Walker and Hadley atmospheric circulations during the Pliocene-Pleistocene climate transition, Earth Planet. Sc. Lett., 297, 103-110, 2010.

Federov, A. V., Dekens, P. S., McCarthy, M., Ravelo, A. C., deMenocal, P. B., Barreiro, M., Pacanowski, R. C., and Philander, S. G.: The Pliocene paradox (mechanisms for a permanent El Niño, Science, 312, 1485-1489, 2006.

Federov, A. V., Brierly, C. M., and Emanuel, K.: Tropical cyclones and permanent El Niño in the early Pliocene epoch, Nature, 463, 1066-1070, 2010.

Forester, R. M. and Bradbury, J. P.: The paleoenvironmental implications of the ostracodes and diatoms from selected samples in Pliocene and Pleistocene lacustrine sediments in the Beaver Basin, Utah, US Geological Survey Open-File Report, 81-390, 53 pp., 1981.

Fox, D. L. and Koch, P. L.: Terestrial history of C4 biomass in the Great Plains, USA, Geology, 31, 809-812, 2003.

Goldner, A., Huber, M., Diffenbaugh, N., and Caballero, R.: Implications of the permanent El Niño teleconnection "blueprint" for past global and North American hydroclimatology, Clim. Past, 7, 723-743, doi:10.5194/cp-7-723-2011, 2011.
Gray, J.: Early Pleistocene paleoclimatic record from Sonoran Desert, Arizona, Science, 133, 38-39, 1961.

Hager, M. W.: Late Pliocene and Pleistocene history of the Donnelly Ranch vertebrate site, south-eastern Colorado, University of Wyoming, Contributions to Geology, Special Paper, 2, 62 pp., 1974.

Hart, W. K., Brueske, P. R., Remme, P. R., and McDonald, H. G.: Chronostratigraphy of the Pliocene Glenns Ferry Formation, Hagerman Fossil Beds national Monument, Idaho, Geol. Soc. Am. Abstr. Prog., 31, A-15, 1999.

Haug, G. H., Tiedemann, R., Zahn, R., and Ravelo, A. C.: Role of Panama uplift on oceanic freshwater balance, Geology, 29, 207210, 2001.

Hay, R. L., Pexton, R. E., Teague, T. T., and Kyser, T. K.: Springrelated carbonate rocks, $\mathrm{Mg}$ clays, and associated minerals in Pliocene deposits of the Amargosa Desert, Nevada and California, Geol. Soc. Am. Bull., 97, 1488-1503, 1986.

Haywood, A. M. and Valdes, P. J.: Modelling middle Pliocene warmth: contribution of atmosphere, oceans and cryosphere, Earth Planet Sc. Lett., 218, 363-377, doi:10.1016/S0012821X(03)00685-X, 2004.

Haywood, A. M., Valdes, P. J., and Peck, V. L.: A permanent El Niño-like state during the Pliocene?, Paleoceanography, 22, PA1213, doi:10.1029/2006PA001323, 2007.

Haywood, A. M., Hill, D. J., Dolan, A. M., Otto-Bliesner, B. L., Bragg, F., Chan, W.-L., Chandler, M. A., Contoux, C., Dowsett, H. J., Jost, A., Kamae, Y., Lohmann, G., Lunt, D. J., Abe-Ouchi, A., Pickering, S. J., Ramstein, G., Rosenbloom, N. A., Salzmann, U., Sohl, L., Stepanek, C., Ueda, H., Yan, Q., and Zhang, Z.: Large-scale features of Pliocene climate: results from the Pliocene Model Intercomparison Project, Clim. Past, 9, 191-209, doi:10.5194/cp-9-191-2013, 2013.

Jansen, E., Overpeck, J., Briffa, K. R., Duplessy, J. C., Joos, F., Masson-Delmotte, V., Olago, D., Otto-Bliesner, B., Peltier, W. R., Rahmstorf, S., Ramesh, R., Raynaud, D., Rind, D., Solomina, O., Villalba, R., and Zhang, D.: Palaeoclimate, in: Climate Change 2007: The Physical Science Basis. Contribution of Working Group I to the Fourth Assessment Report of the Intergovernmental Panel on Climate Change, edited by: Solomon, S., Qin, D., Manning, M., Chen, Z., Marquis, M., Averyt, K. B., Tignor, M., and Miller, H. L., Cambridge University Press, Cambridge, United Kingdom and New York, NY, USA, 2007.

Kim, S. T. and O'Neil, J. R.: Equilibrium and non-equilibrium oxygen isotope effects in synthetic carbonates, Geochim. Cosmochim. Ac., 61, 3461-3475, 1997.

Lawrence, K. T., Liu, Z., and Herbert, T. D.: Evolution of the eastern tropical Pacific through Plio-Pleistocene glaciation, Science, 312, 79-83, 2006.

Litwin, R. J. and Andrle, V. A. S.: Palynomorph census data from Pliocene strata of the U.S. Atlantic Coastal Plain (Massachusetts to central Florida), US Geol. Surv. Open-File Rep., 92-262, 1992.

Liu, B., Phillips, F. M., and Campbell, A. R.: Stable carbon and oxygen isotopes of pedogenic carbonate, Ajo Mountains, southern Arizona: implications for paleoenvironmental change, Palaeogeogr. Palaeocl., 124, 233-246, 1996.

Mack, G. H., Cole, C. R., James, W. C., Giordano, T. H., and Salyards, S. L.: Stable oxygen and carbon isotopes of pedogenic carbonate as indicators of Plio-Pleistocene paleoclimate in the 
Southern Rio Gradne Rift, South-Central New Mexico, Am. J. Sci., 294, 621-640, 1994.

Maslin, M. A., Haug, G. H., Sarnthein, M., Tiedemann, R., Erlenkeuser, H., and Stax, R.: Northwest Pacific Site 882: The initiation of Northern Hemisphere glaciation, Proc. ODP Sci. Res., 145, 315-332, 1995.

McFadden, L. D. and Tinsley, J. C.: Rate and depth of pedogeniccarbonate accumulation in soils: Formulation and testing of a compartment model, in: Soils and Quaternary Geology of the Southwestern United States, edited by: Wide, D. L., Geol. S. Am. S., 203, 23-42, 1985.

McFadden, L. D., Amundson, R. G., and Chadwick, O. A.: Numerical modeling, chemical and isotopic studies of carbonate accumulation in soils of arid regions, in: Occurrence, Characteristics, and Genesis of Carbonate, Gypsum and Silica Accumulations in Soils, edited by: Nettleton, W. D., SSSA Spec. Publ., 26, 17-35, 1991.

Meehl, G. A., Stocker, T. F., Collins, W. D., Friedlingstein, P., Gaye, A. T., Gregory, J. M., Kitoh, A., Knutti, R., Murphy, J. M., Noda, A., Raper, S. C. B., Watterson, I. G., Weaver, A. J., and Zhao, Z.-C.: Global Climate Projections, in: Climate Change 2007: The Physical Science Basis. Contribution of Working Group I to the Fourth Assessment Report of the Intergovernmental Panel on Climate Change, edited by: Solomon, S., Qin, D., Manning, M., Chen, Z., Marquis, M., Averyt, K. B., Tignor, M., and Miller, H. L., Cambridge University Press, Cambridge, United Kingdom and New York, NY, USA, 2007.

Mix, H. T., Mulch, A., Kent-Corson, M. L., and Chamberlain C. P.: Cenozoic migration of topography in the North American Cordillera, Geology 39, 87-90, 2011.

Molnar, P. and Cane, M. A.: El Niño's tropical climate and teleconnections as a blueprint for pre-Ice Age climates, Paleoceanography, 17, PA1021, doi:10.1029/2001PA000663, 2002.

Mudelsee, M. and Raymo, M. E.: Slow dynamics of the Northern Hemisphere glaciation, Paleoceanography, 20, PA4022, doi:10.1029/2005PA001153, 2005.

Mulch, A., Graham, S. A., and Chamberlain, C. P.: Hydrogen isotopes in Eocene river gravels and paleoelevation of the Sierra Nevada, Science, 313, 87-89, 2006.

Nations, J. D., Hevly, R. H., Blinn, D. W., and Landye, J. J.: Paleontology, paleoecology, and depositional history of the MiocenePliocene Verde Formation, Yavapai County, Arizona, Arizona Geological Society Digest, 13, 133-149, 1981.

O'Gorman, P. and Schneider, T.: Scaling of precipitation extremes over a wide range of climates simulated with and idealized GCM climate, J. Climate, 22, 5676-5685, 2009.

Pagani, M., Liu, Z., LaRiviere, J., and Ravelo A. C.: High Earthsystem climate sensitivity determined from Pliocene carbon dioxide concentrations, Nat. Geosci., 3, 27-30, 2010.

Pausata, F. S. R., Battisti, D. S., Nisancioglu, K. H., and Bitz, C. M.: Chinese stalagmite $\delta^{18} \mathrm{O}$ controlled by changes in the Indian monsoon during a simulated Heinrich event, Nat. Geosci., 4, 474-480, 2011.

Peters, N. A., Huntington, K. W., and Hoke, G. D.: Hot or not? Impact of seasonally variable soil carbonate formation on paleotemperature and O-isotope records from clumped isotope thermometry, Earth Planet. Sc. Lett., 361, 208-218, 2013.

Poulsen, C. J., Ehlers T. A., and Insel, N.: Onset of convective rainfall during gradual Late Miocene rise of the Central Andes, Sci- ence, 328, 490-493, 2010.

Quade, J., Cerling, T. E., and Bowman, J. R.: Systematic variations in the carbon and oxygen isotopic composition of pedogenic carbonate along elevational transects in the southern Great Basin, United States, Geol. Soc. Am. Bull., 101, 464-475, 1989.

Ravelo, A. C., Andreasen, D. H., Lyle, M., Lyle, A. O., and Wara, M. W.: Regional climate shifts caused by gradual global cooling in the Pliocene epoch, Nature, 429, 263-267, 2004.

Raymo, M. E., Grant, B., Horowitz, M., and Rau, G. H.: MidPliocene warmth: stronger greenhouse and stronger conveyor, Mar. Micropaleontol., 27, 313-326, 1996.

Remeika, P., Fischbein, I. W., and Fischbein, S. A.: Lower Pliocene petrified wood from the Palm Springs Formation, Anza Borrego Desert State Park, California, Rev. Palaeobot. Palyno., 56, 183198, 1988.

Repenning, C. A.: Biochronology of the microtine rodents of the United States, in: Cenozoic Mammals of North America, edited by: Woodburne, M. O., University of California Press, 236-267, 1987.

Retallack, G. J.: Late Miocene climate and life on land in Oregon within a context of Neogene global change, Palaeogeogr. Palaeocl., 214, 97-123, 2004.

Retallack, G. J.: Pedogenic carbonate proxies for amount and seasonality of precipitation in paleosols, Geology, 33, 333-336, 2005.

Ropelewski, C. F. and Halpert, M. S.: North American precipitation and temperature patterns associated with the El Niño-Southern Oscillation (ENSO), Mon. Weather Rev., 114, 2352-2362, 1986.

Rozanski, K., Araguas-Arrguas, L., and Gonfiantini, R.: Isotopic patterns in modern global precipitation, in: Climate Change in Continental Isotopic Records, edited by: Swart, P. K., Lohmann, K. C., McKenzie, J., and Savin, S., American Geophysical Union Geophysical Monograph, 78, 1-37, 1993.

Sadler, J. L. and Link, P. K.: The Tuana Gravel: Early Pleistocene response to longtitudinal drainage of a late-stage rift basin, western Snake River Plain, Northwest Geology, 26, 46-62, 1996.

Seager, R., Ting, M., Held, I., Kushnir, Y., Lu, J., Vecchi, G., Huang, H.-P., Harnik, N., Leetmaa, A., Lau, N.-C., Li, C., Velez, J., and Naik, N.: Model projections of an imminent transition to a more arid climate in Southwestern North America, Science, 316, 1181-1184, 2007.

Shukla, S. P., Chandler, M. A., Jonas, J., Sohl, L. E., Mankoff, K., and Dowsett, H.: Impact of a permanent El Niño (El Padre) and Indian Ocean Dipole in warm Pliocene climates, Paleoceanography, 24, PA2221, doi:10.1029/2008PA001682, 2009.

Smith, G. I.: Paleohydrologic regimes in the southwestern Great Basin, 0-3.2 my ago, compared with other long records of "global" climate, Quaternary Res., 22, 1-17, 1984.

Smith, G. I.: Fish Speciation in a Western North American Pliocene Rift Lake, Palaios, 2, 436-445, 1987.

Sohl, L. E., Chandler, M. A., Schmunk, R. B., Mankoff, K., Jonas, J. A., Foley, K. M., and Dowsett, H. J.: PRISM3/GISS topographic reconstruction, US Geological Survey Data Series, 419, 6 pp., 2009.

Stevenson, B. A., Kelly, E. F., McDonald, E. V., Busacca, A. J., and Welker J. M.: Oxygen isotope ratios in Holocene carbonates across a climatic gradient, eastern Washington State, USA: Evidence for seasonal effects on pedogenic mineral isotopic composition, Holocene, Holocene, 20, 575-583, 2010. 
Thompson, R. S.: Pliocene environments and climates in the western United States, Quaternary. Sci. Rev., 10, 115-132, 1991.

Trenberth, K. E., Branstator, G. W., Karoly, D., Kumar, A., Lau, N.C., and Ropelewski, C.: Progress during TOGA in understanding and modeling global teleconnections associated with tropical sea surface temperatures, J. Geophys. Res., 103, 14291-14324, 1998.

Van den Dool, H., Huang, J., and Fan, Y.: Performance and Analysis of the constructed analogue method applied to US soil moisture applied over 1981-2001, J. Geophys. Res., 108, 1-16, 2003.

Vizcaíno, M., Rupper, S., and Chiang, J. C. H.: Permanent El Niño and the onset of Northern Hemisphere glaciations: Mechanism and comparison with other hypotheses, Paleoceanography, 25, PA2205, doi:10.1029/2009PA001733, 2010.

Wagner, J. D. M., Cole, J. E., Beck, J. W., Patchett, P. J., Henderson, G. M., and Barnett, H. R.: Moisture variability in the southwestern United States linked to abrupt glacial climate change, Nat. Geosci., 3, 110-113, 2010.

Wang, Y., Cerling, C. E., Quade, J., Bowman, J. R., Smith, G. A., and Lindsay, E. H.: Stable isotopes of paleosols and fossil teeth as paleoclimate indicators: An example from the St. David Formation, Arizona, Geoph. Monog. Series, 78, 241-248, 1993.
Wara, M. W., Ravelo, A. C., and Delaney, M. L.: Permanent El Niño-like conditions during the Pliocene warm period, Science, 29, 758-761, 2005.

Welker, J. M.: Isotopic $\left(\delta^{18} \mathrm{O}\right)$ characteristics of weekly precipitation collected across the USA: An initial analysis with application to water source studies, Hydrol. Process., 14, 1449-1464, 2000.

Welker, J. M.: ENSO effects on $\delta^{18} \mathrm{O}, \delta^{2} \mathrm{H}$ and d-excess values in precipitation across the U. S. using a high-density, long-term network (USNIP), Rapid Commun. Mass Sp., 26, 1893-1898, 2012.

Willard, D. A., Cronin, T. M., Ishman, S. E., and Litwin, R. J.: Terrestrial and marine records of climate and environmental change during the Pliocene in subtropical Florida, Geology, 21, 679$682,1993$.

Wolfe, J. A.: Estimates of Pliocene precipitation and temperature based on multivariate analysis of leaf physiognomy, in: Pliocene Climates: Scenario for Global Warming, edited by: Gosnell, L. B. and Poore, R. Z., US Geological Survey Open-File Report, 90-64, 39-42, 1990.

Zachos, J., Pagani, M., Sloan, L., Thomas, E., and Billups K.: Trends, rhythms, and aberrations in global climate $65 \mathrm{Ma}$ to present, Science, 292, 686-693, 2001. 